Research Article

\title{
Multianalysis Characterization of Mineralogical Properties of Copper-Lead-Zinc Mixed Ores and Implications for Comprehensive Recovery
}

\author{
Qian Zhang, ${ }^{1}$ Shuming Wen, ${ }^{1}$ Qicheng Feng $\mathbb{D}^{1},{ }^{1}$ Song Zhang, ${ }^{2}$ and Wenlin Nie ${ }^{1}$ \\ ${ }^{1}$ State Key Laboratory of Complex Nonferrous Metal Resources Clean Utilization, Faculty of Land Resource Engineering, \\ Kunming University of Science and Technology, Kunming 650093, China \\ ${ }^{2}$ Kunming Natural Resources Survey Center, China Geological Survey, Kunming 650100, China
}

Correspondence should be addressed to Qicheng Feng; fqckmust@163.com

Received 22 August 2020; Revised 24 September 2020; Accepted 12 November 2020; Published 26 November 2020

Academic Editor: Sakar Mohan

Copyright (C) 2020 Qian Zhang et al. This is an open access article distributed under the Creative Commons Attribution License, which permits unrestricted use, distribution, and reproduction in any medium, provided the original work is properly cited.

Copper-lead-zinc mixed ore in Tibet, China, is a complex and refractory polymetallic ore resource; thus, ascertaining its mineralogical properties is very important for comprehensive recovery of valuable elements. In this work, the mineralogical properties of this copper-lead-zinc mixed ore have been characterized in detail following a multidisciplinary approach, including chemical, phase, $\mathrm{x}$-ray diffraction (XRD), electron microprobe, and mineral liberation analyses. The results show that the raw ore contained $0.53 \% \mathrm{Cu}, 1.29 \% \mathrm{~Pb}$, and $0.54 \% \mathrm{Zn}$; the oxidation rates of copper, lead, and zinc were $40.21 \%, 79.31 \%$, and $84.83 \%$, respectively. The Au and $\mathrm{Ag}$ contents in the raw ore were $0.28 \mathrm{~g} / \mathrm{t}$ and $23.6 \mathrm{~g} / \mathrm{t}$, which can be comprehensively utilized along with the recovery of copper, lead, and zinc. The gangue mainly contained $\mathrm{SiO}_{2}, \mathrm{CaO}$, and $\mathrm{Al}_{2} \mathrm{O}_{3}$. Copper in the raw ore mainly existed in bornite, duftite, chalcopyrite, and chrysocolla; lead mainly existed in cerussite, duftite, and galena; zinc mainly existed in willemite, hemimorphite, and sphalerite. The complexity in the embedding and wrapping relationships, fine-grained dissemination, high oxidation, and considerable differences in the floatability of various minerals result in difficulties in recovering the target minerals using a single method. Based on the systematic mineralogical properties obtained, an integrated technology of "bulk flotation-oxidation roasting-hydrometallurgy" has been proposed to enrich and separate copper, lead, and zinc in the ore, providing new ideas for the comprehensive and efficient utilization of polymetallic mineral resources in Tibet.

\section{Introduction}

Mineral resources are not only indispensable materials for modern national economic construction, but also the material basis for economic development. With the development of the economy, single easy-to-handle ores have gradually been exhausted, and the utilization of complex polymetallic refractory mineral resources has become inevitable [1]. The complexity of a polymetallic ore beneficiation process is determined by the complex nature of the ore. In the mineral separation process, advanced equipment, circuits, and new reagent systems can be used to improve the quality and recovery rate of refractory ores, but to select a rational process, comprehensive research is necessary to determine the location and distribution of target elements, as well as the occurrence states of target minerals, and the types and distribution features of minerals. The mineral processing steps are determined on the basis of detailed mineralogy study of the complex ore [2]. Therefore, detailed mineralogy studies are required to provide mineralogical guidance for subsequent separation operations [3-5]. In recent years, with the rapid development of science and technology, mineral liberation analysis, electron microprobes, Leica DMLP light microscopy, and other detection methods have been applied to the field of process mineralogy [6-9]. Copper-lead-zinc deposits are widely distributed, and largescale reserves of these resources are found in China. They have great developmental value, but these minerals are usually closely symbiotic, making the separation of copper-lead-zinc ore very difficult, the quality of the concentrate poor, and the recovery rate low $[10,11]$. 
TABLe 1: Chemical multiple element analysis of raw ore (\%).

\begin{tabular}{lccccccccccccccccc}
\hline Component & $\mathrm{Pb}$ & $\mathrm{Zn}$ & $\mathrm{Cu}$ & $\mathrm{TiO}_{2}$ & $\mathrm{Al}_{2} \mathrm{O}_{3}$ & $\mathrm{Fe}$ & $\mathrm{K}$ & $\mathrm{Na}$ & $\mathrm{S}$ & $\mathrm{Si}$ & $\mathrm{CaO}$ & $\mathrm{MgO}$ & $\mathrm{SiO}_{2}$ & $\mathrm{As}$ & $\mathrm{F}$ & $\mathrm{Au}(\mathrm{g} / \mathrm{t})$ & $\mathrm{Ag}(\mathrm{g} / \mathrm{t})$ \\
\hline Content & 1.29 & 0.54 & 0.53 & 0.012 & 7.02 & 6.89 & 0.59 & 0.18 & 0.45 & 17.23 & 34.46 & 1.08 & 35.70 & 0.23 & 0.45 & 0.28 & 23.6 \\
\hline
\end{tabular}

TABle 2: Phase analysis results of copper (\%).

\begin{tabular}{lccccc}
\hline Phase & Copper vitriol & Free copper oxide & Combined copper oxide & Copper sulfide and others & Total copper \\
\hline Content & $<0.001$ & 0.093 & 0.100 & 0.280 & 0.473 \\
Occupancy & $<0.21$ & 19.66 & 21.14 & 59.20 & 100.00 \\
\hline
\end{tabular}

TABLE 3: Phase analysis results of lead (\%).

\begin{tabular}{lccccc}
\hline Phase & Lead sulfate & Lead carbonate & Lead sulfide & Plumbojarosite and others & Total lead \\
\hline Content & 0.30 & 0.55 & 0.24 & 0.07 & 1.16 \\
Occupancy & 25.86 & 47.41 & 20.69 & 6.03 & 100.00 \\
\hline
\end{tabular}

TABle 4: Phase analysis results of zinc (\%).

\begin{tabular}{lccccc}
\hline Phase & Zinc sulfate & Oxide & Sulfide & Franklinite and others & Total zinc \\
\hline Content & 0.061 & 0.41 & 0.088 & 0.024 & 0.583 \\
Occupancy & 10.46 & 70.33 & 15.09 & 4.12 & 100.00 \\
\hline
\end{tabular}

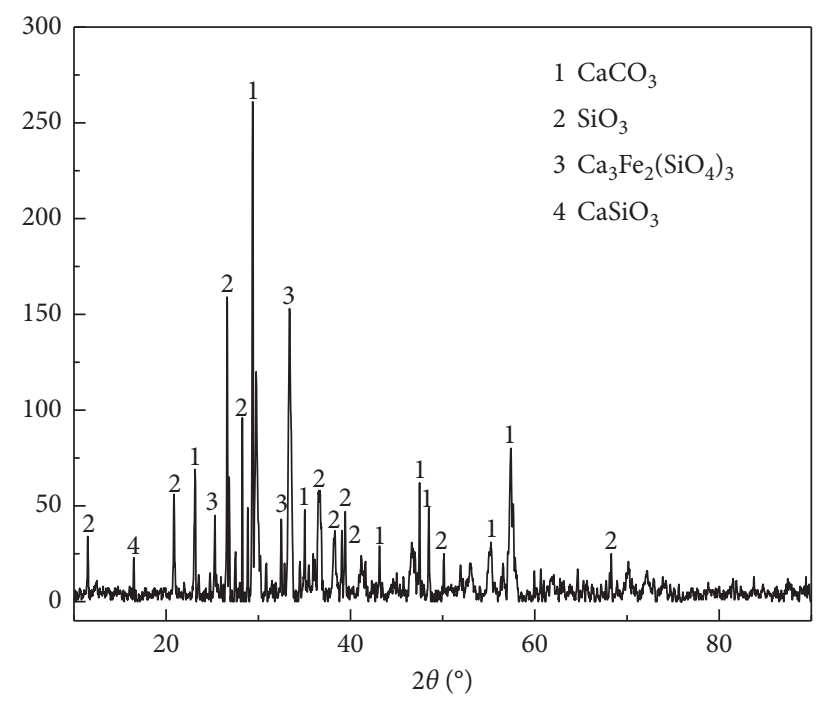

FIgURE 1: X-ray analysis results of the raw ore.

As has been well established, the minerals of copper, lead, and zinc are naturally associated with each other, whether in oxidized ores or in sulfide ores [12]. Conventionally, such mixed ores have been treated by pre-concentration and differential froth flotation [13]. At present, over $50 \%$ of copper, lead, and zinc in the world are produced by pyrometallurgical processes. Significant interest has developed in the extraction of copper, lead, and zinc from lowgrade/low-quality ores and concentrates via hydrometallurgical process, especially for the separation of copper-leadzinc tailings [14-18]. Wills' Mineral Processing Technology introduced various ore processing techniques from raw feeds to concentrates [19]. Copper-lead-zinc oxide minerals are readily leached by any acidic solution and oxidative bioleaching [20]. To improve the leaching rate, high leaching temperatures and high concentrations of strong oxidants are needed to increase oxidation kinetics [21]. However, mostly sulfide ores are recovered by flotation [22-28]. The flotation depressing behavior and adsorption mechanism of galena have been investigated by a series of experiments; the results showed that macromolecular polymer polyacrylamideallylthiourea (PAM-ATU) was an effective depressant for galena in separation from chalcopyrite [29]. Flotation research on galena indicated that higher flotation recovery was achieved under the conditions of straight chain xanthates as collector and methyl isobutyl carbinol as frother [30]. For a 
TABLE 5: Mineral composition and particle size distribution.

\begin{tabular}{|c|c|c|c|c|c|c|}
\hline Types & Minerals & Particle size $(\mathrm{mm})$ & Content (\%) & Minerals & Particle size $(\mathrm{mm})$ & Content (\%) \\
\hline \multirow{5}{*}{$\begin{array}{l}\text { Sulfide } \\
\text { Sulfate }\end{array}$} & Chalcopyrite & $0.005-4$ & 0.27 & Chalcocite & $0.004-0.05$ & 0.03 \\
\hline & Covellite & $0.004-0.01$ & 0.02 & Bornite & $0.05-0.1$ & 0.18 \\
\hline & Enargite & $0.004-0.06$ & 0.04 & Bronze & $0.02-0.6$ & 0.03 \\
\hline & Galena & $0.01-0.5$ & 0.21 & Sphalerite & $0.01-2$ & 0.25 \\
\hline & Pyrite & $0.01-0.02$ & 0.20 & Tetrahedrite & $0.004-0.01$ & 0.20 \\
\hline Oxides & Quartz & $0.01-0.5$ & 6.13 & Limonite & $0.01-0.2$ & 1.30 \\
\hline \multirow{6}{*}{ Silicate phosphate } & Chrysocolla & $0.02-0.3$ & 0.30 & Hemimorphite & $0.004-0.075$ & 0.52 \\
\hline & Albite & $0.1-0.2$ & 2.20 & Wollastonite & $0.01-0.3$ & 9.46 \\
\hline & Chlorite & $0.01-0.1$ & 0.26 & Muscovite & $<0.004$ & 1.58 \\
\hline & Andradite & $0.05-3$ & 24.98 & Essonite & - & 23.00 \\
\hline & Magnesium & - & 0.29 & Vesuvianite & $0.1-0.7$ & 1.01 \\
\hline & Ellestadite & $0.004-0.15$ & 0.86 & Apatite & $0.004-0.075$ & 0.34 \\
\hline Arsenate & Duftite & $0.004-0.15$ & 0.80 & Austinite & $0.004-0.05$ & 0.01 \\
\hline \multirow{3}{*}{$\begin{array}{l}\text { Carbonate } \\
\text { Fluoride }\end{array}$} & Malachite & $0.1-0.5$ & 0.06 & Rosasite & $0.004-0.075$ & 0.07 \\
\hline & Cerussite & $0.1-0.5$ & 0.98 & Smithsonite & $0.004-0.05$ & 0.08 \\
\hline & Calcite & $0.02-2.4$ & 15.52 & Fluoride & $0.02-3.5$ & 0.95 \\
\hline
\end{tabular}
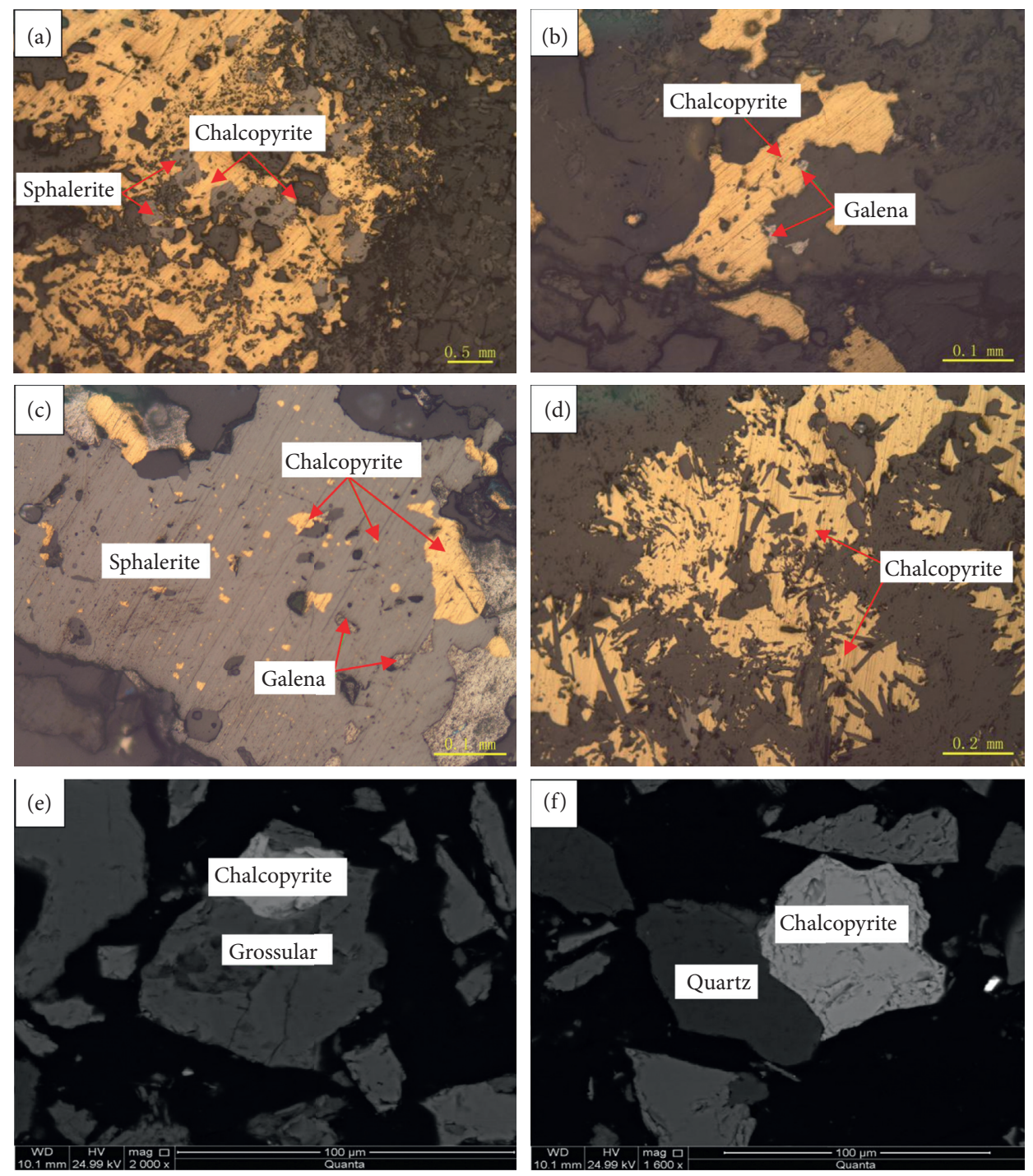

FIgURE 2: Embedded characteristics of chalcopyrite. 

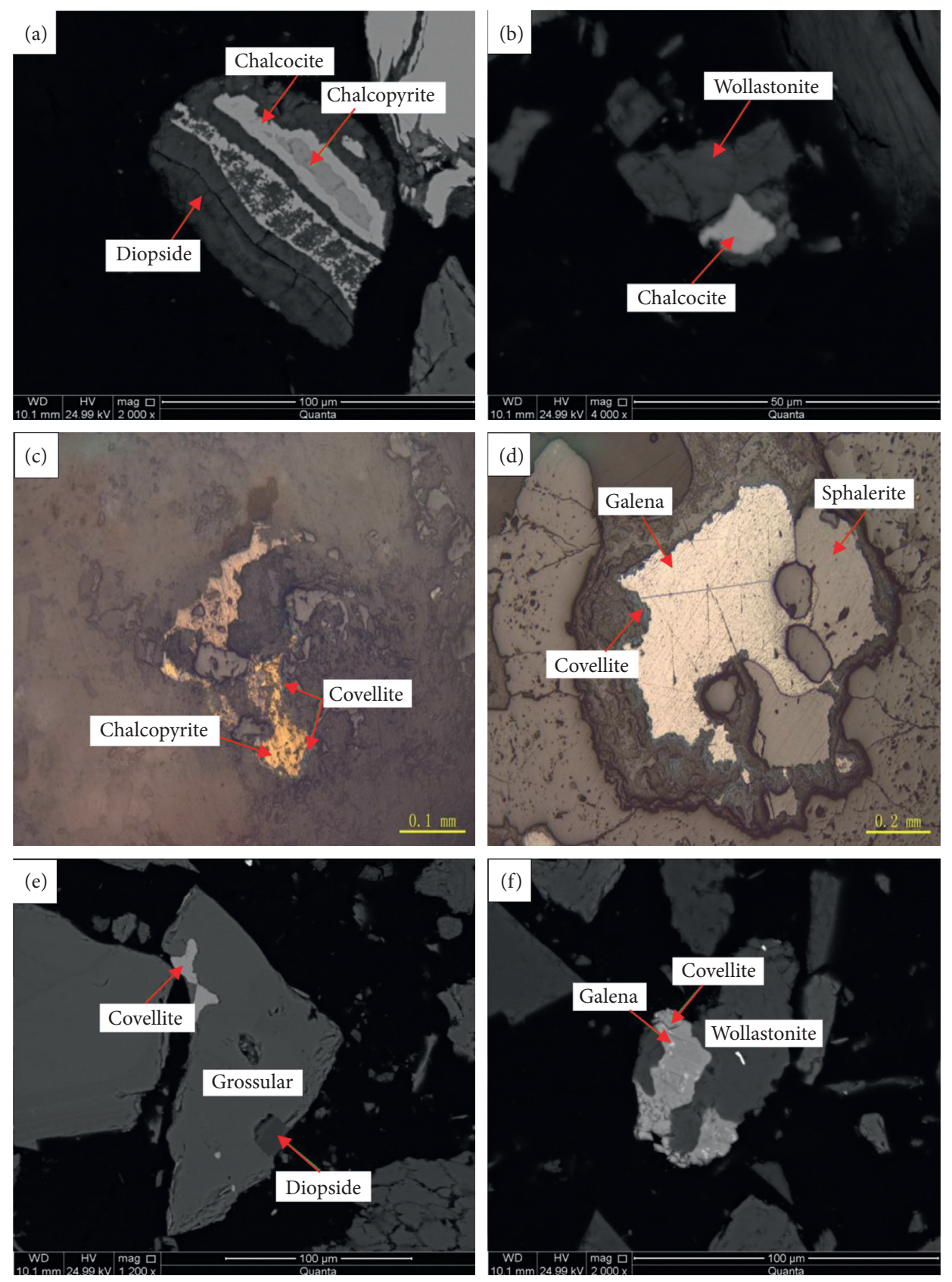

FIGURE 3: Embedded characteristics of chalcocite and covellite.

lead-zinc sulfide composite ore from the Rosh Pinah Mine, Seke and Pistorius used batch flotation for selective flotation of galena and sphalerite. The results showed that cuprous cyanide complexes can activate sphalerite, and the activation and subsequent flotation of sphalerite was greater when the composite was dry-milled than when it was wet-milled [31]. Flotation of oxidized pyrite was conducted after ultrasonic pretreatment (5-60 min) or in $\mathrm{CO}_{2}$-saturated water with $\mathrm{pH}$ range of 3-10; the results showed that over $90 \%$ mineral particles were achieved in less than $30 \mathrm{~s}$ after $15 \mathrm{~min}$ of sonication in $\mathrm{CO}_{2}$-saturated DI water at $4-7^{\circ} \mathrm{C}$ [32]. Many factors such as diffusiophoretic motion, attachment through rotation of angular particles, dynamic contact angles, older surfaces, solubility, surface stress, and the rate of adsorption influenced the flotation recovery. Besides, an appropriate environment might improve the flotation separation of ultrafines [33]. With the development of new deposits, the grain sizes and intergrowth of valuable and gangue minerals have remained topics of increasing interest, and reagents and technology have been successfully used for selective separation of copper-lead-zinc complex ores [34].

Copper-lead-zinc ore from Tibet has many disadvantageous characteristics, such as complex components, a high oxidation rate, strong association between different elements, and fine grain size of the inlay, which make the development and utilization of these mineral resources 

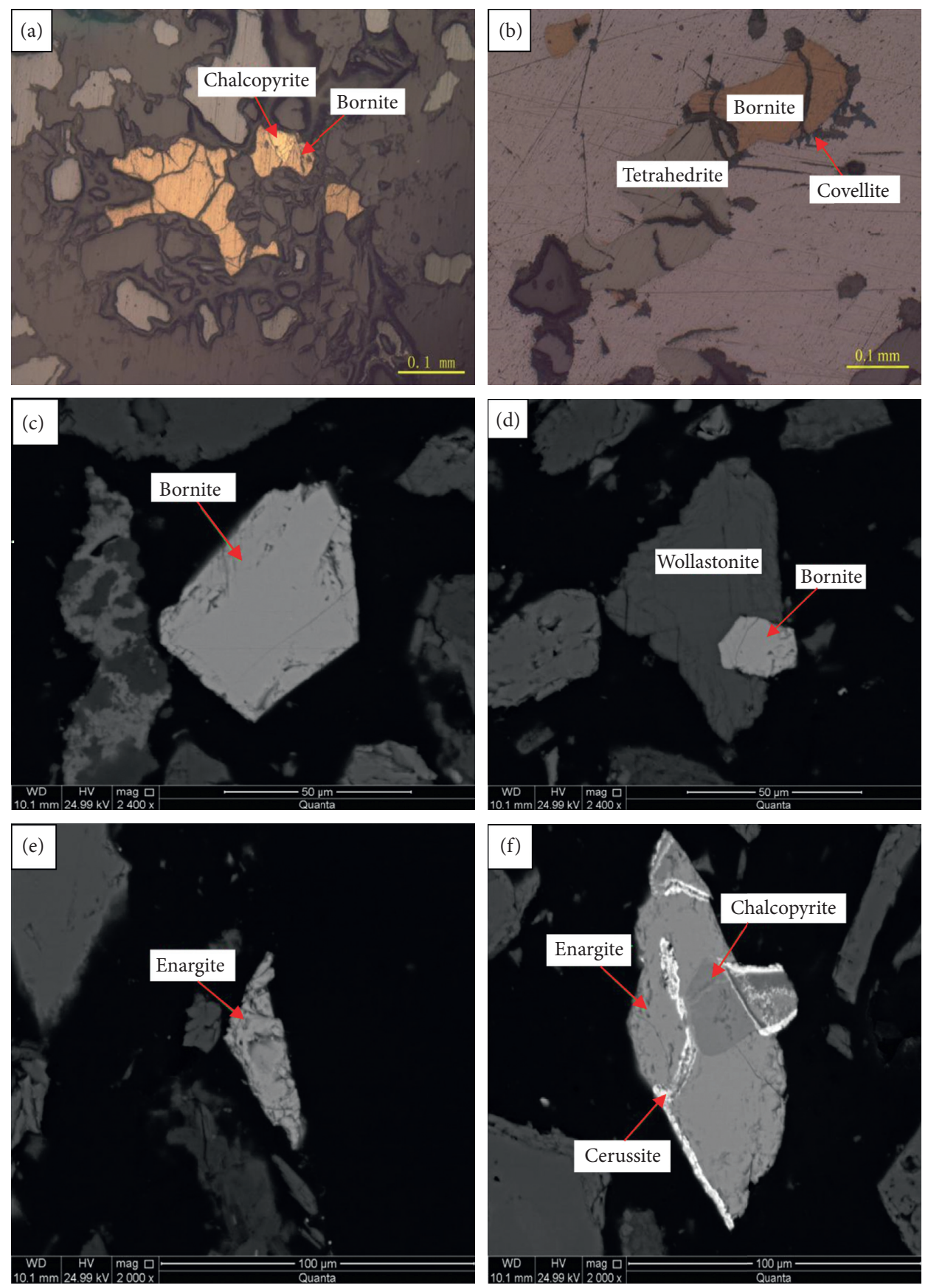

Figure 4: Embedded characteristics of bornite and enargite.

extremely difficult [35]. Tibet is located in a high-altitude area, with low oxygen levels and a fragile ecological environment. To develop and utilize ore from the region, it is necessary to follow the development model of "development and protection in parallel" to minimize damage to the ecological environment. Therefore, it is necessary to study the mineralogical characteristics of the ore before considering the technical process of separation. For this paper, we investigated the contents and compositions of minerals, mineral liberation, mineral inlay relationships, and so on, using many analytical methods including multielement analysis, phase analysis, $\mathrm{x}$-ray diffraction (XRD) analysis, electron microprobe analysis (EMPA), and mineral liberation analysis (MLA). Finally, a "flotation-hydrometallurgy" combined technology process was used to comprehensively recover the target mineral elements, which provides a basis for later development and utilization.

\section{Materials and Methods}

2.1. Materials. The ore sample was taken from a mineral processing plant of Huatailong Mining Development Ltd. in Tibet, associated with Gold Group Co., China. A large sample was selected for mineralogical analysis at the 

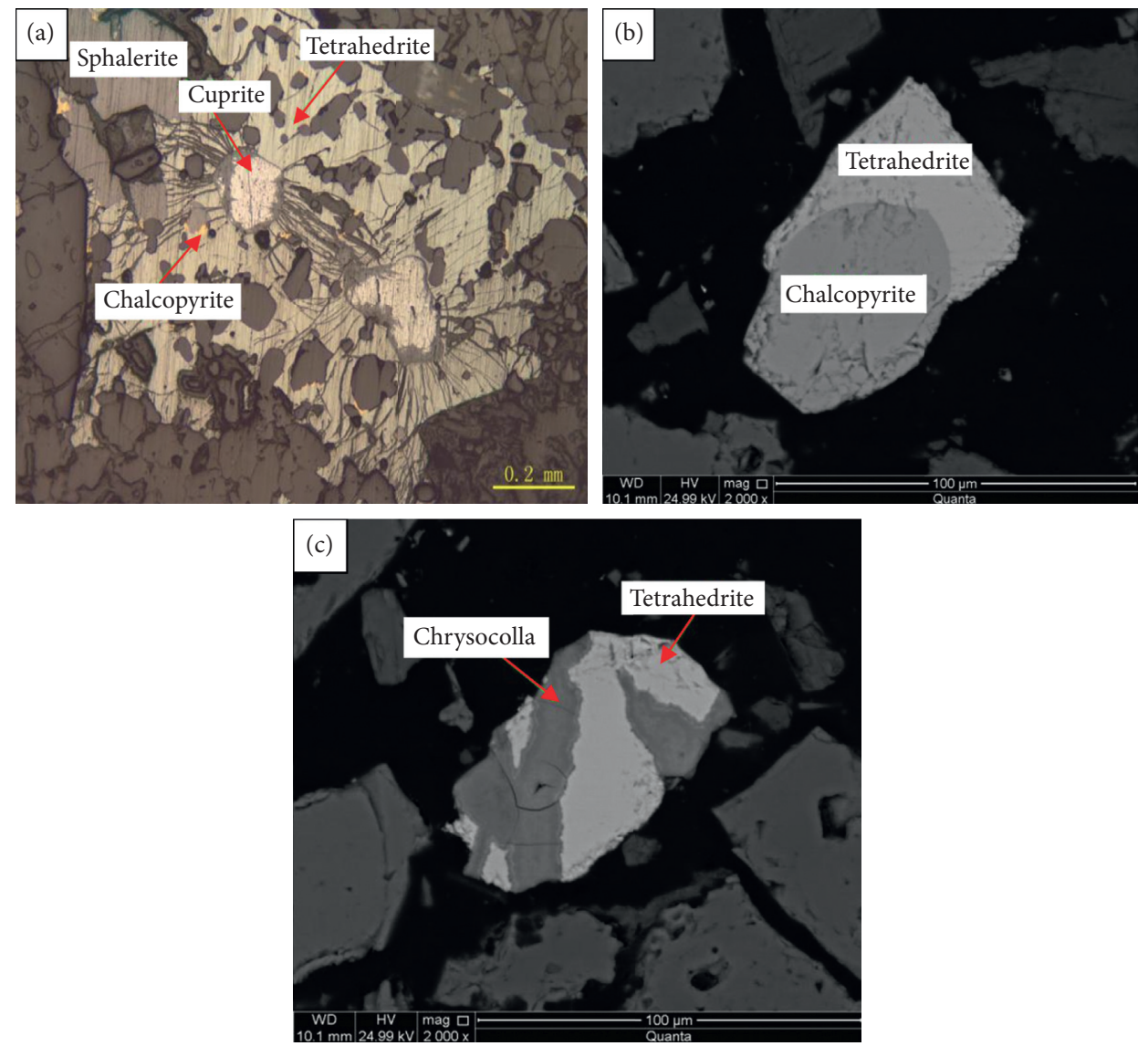

FIgURE 5: Embedded characteristics of tetrahedrite.

Kunming Institute of Metallurgical Research, Yunnan Provincial Nonferrous Metals and Products Quality Supervision and Inspection Station.

2.2. Research Methods. X-ray diffraction (XRD) analysis was conducted using the sharp-shadow $\mathrm{X}$-ray diffraction analyzer from Dutch PANalytical ( $\mathrm{Cu}$ target $\mathrm{K} \alpha$ ray, graphite monochromator filter, voltage $40 \mathrm{kV}$, and current $40 \mathrm{~mA}$ ); the range of instrument scanning was $0^{\circ}-80^{\circ}$, and the scanning speed was $8 \% \mathrm{~min}$. Electron microprobe analysis (EMPA) was conducted using a JXY-8230 electron microprobe (Japan). The characteristic X-rays of the sample elements were stimulated through a fine focus electron beam incident on the surface of the sample. The mineral contents were determined based on $\mathrm{x}$-ray wavelengths; the voltage was $20 \mathrm{kv}$, the beam current was $1 \times 10^{-8} \mathrm{~A}$, and the diameter was $1 \mu \mathrm{m}$.

The sample was ground to make a light sheet and 133,194 particles were analyzed and automatically counted to determine the sizes of the main minerals in the ore by the detecting instrument of a microscope and mineral liberation analysis (MLA). The dissemination conditions and physicochemical properties of the main minerals in the ore were determined using experimental devices such as a stereo microscope, a scanning electron microscope, and a reflection microscope. The MLA (Quanta 650) instrument is from FEI
(City, State, USA). It comprises a scanning electron microscope, two x-ray energy spectrum probes, and a set of automated analysis software systems for mineralogy; the test voltage was $20 \mathrm{kv}$, and the current was $40.1 \mu \mathrm{A}$.

\section{Results and Discussion}

3.1. Chemical Composition and Phase Analysis of Raw Ores. Chemical multielement analysis was conducted to identify the main elements and their contents in the ore and to determine the valuable elements mainly recovered from the ore; the results are shown in Table 1. The mineral composition was tested by phase analysis; the results are shown in Tables 2-4.

Table 1 shows that the ore contains $0.53 \% \mathrm{Cu}, 1.29 \% \mathrm{~Pb}$, and $0.53 \% \mathrm{Zn}$; the gangue components mainly are $\mathrm{CaO}$ and $\mathrm{SiO}_{2}$; some gangue material will float to the mixed concentrate with useful minerals. The alkaline substance $\mathrm{CaO}$ will increase the amount of sulfuric acid in the leaching process; simultaneously, the product $\mathrm{CaSO}_{4}$ will remain in the leaching slag, which reduces the grade of $\mathrm{Pb}$. If the $\mathrm{SiO}_{2}$ content is too high, the product of flocculated viscous silicic acid forms, which will make the filtrate thick and difficult to filter.

Table 2 shows that the copper minerals in the ore are mainly copper sulfide, the distribution rate of which is $59.20 \%$. The distribution rate of copper oxide is $40.80 \%$. 

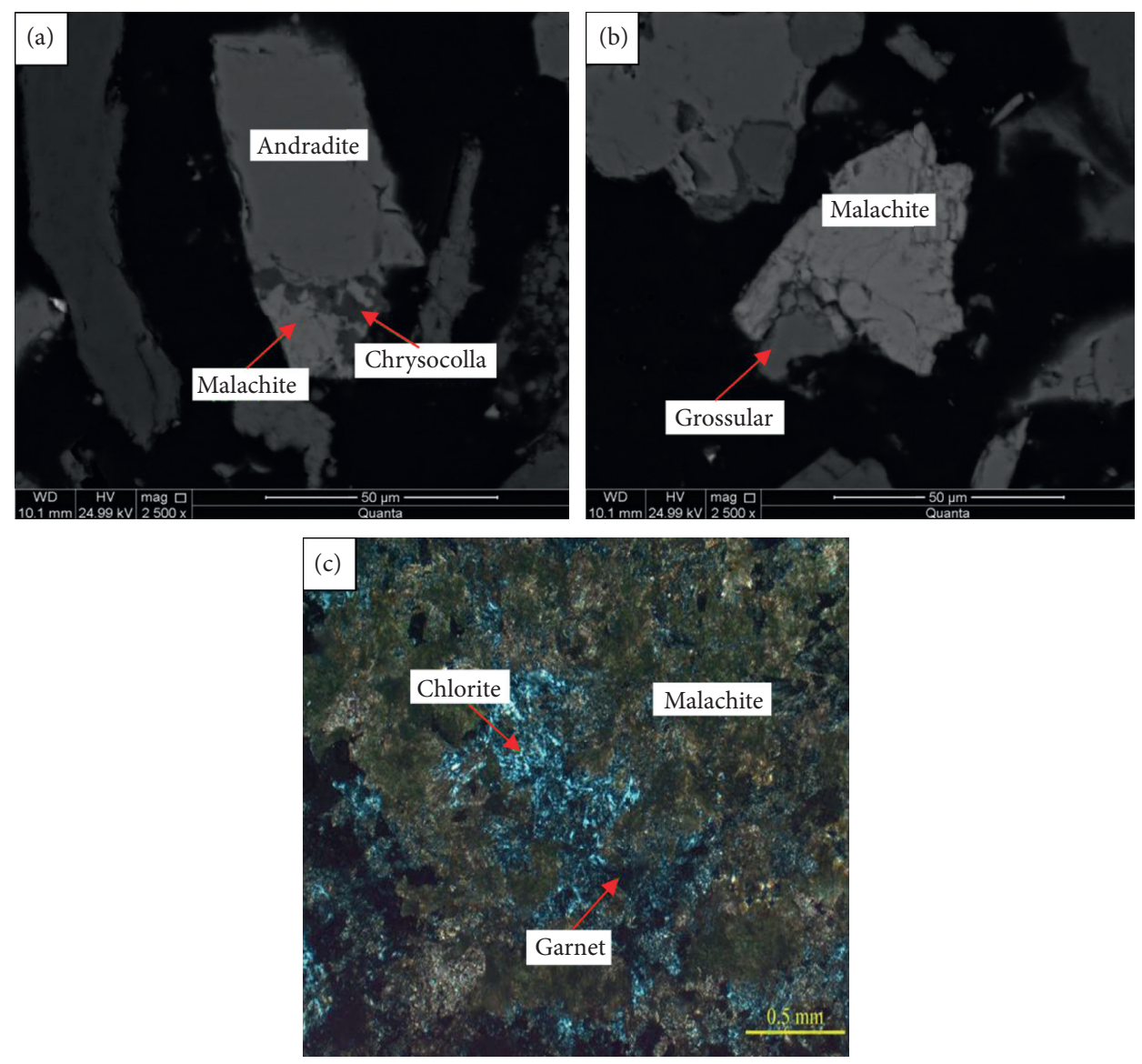

FIGURE 6: Embedded characteristics of malachite.

Copper sulfide and free copper oxide are the main minerals for the extraction of copper.

Table 3 shows that lead minerals mainly existed in the form of lead carbonate, at a distribution rate of $47.41 \%$, followed by lead sulfate, at a distribution rate of $25.86 \%$; the distribution rate of lead sulfide was only $20.69 \%$. Plumbojarosite and other components comprised 6.03\%. Lead carbonate and lead sulfide are the main lead minerals for extracting lead.

Table 4 shows that most of zinc minerals in the ore were oxides, with a distribution rate as high as $70.33 \%$. Zinc in the sulfides was $15.09 \%$, zinc in the zinc sulfate comprised $10.46 \%$, and $4.14 \%$ of zinc was present in franklinite and other forms. Zinc sulfide minerals are the main minerals for extracting zinc, and some zinc can also be extracted from zinc oxide minerals such as smithsonite and hemimorphite.

In general, sulfide ore is separated by direct flotation and useful minerals can be recovered from oxidized ore by flotation and leaching [36-38]. According to the results of the phase analysis of copper, lead, and zinc, the ore comprises both copper oxide minerals and copper sulfide minerals; it is a typical oxygen-sulfur mixed copper ore of low grade, high oxidation, and a high combination rate, for which recovery by flotation is extremely difficult. The lead is characterized by a typical low-grade lead oxide ore, for which recovery by flotation is also very difficult. The original ore grade of the zinc is far lower than the tailings grade of zinc ore dressing plants in China and around the world, and the oxidation rate of zinc is as high as $84.83 \%$, which makes recovery by flotation difficult. Therefore, flotation may be used to maximize the recovery of sulfide minerals and partially oxidized minerals, which are separated by hydrometallurgical methods. In the flotation process, a large amount of sodium sulfide should be added to pulp for sulfide regents of the oxidized ores so that it functions with a collector and facilitating flotation.

3.2. Ore Structure. The color of the ore is mainly gray-yellow. In some ores, the content of metal minerals such as chalcopyrite, galena, and sphalerite accounts for $60 \%-75 \%$, which constitutes the sub-block-block structure of the ore. In most of the ore, malachite and chrysocolla are disseminated and form a disseminated ore structure; another part of the ore has a layered structure. The main structures of metal minerals in the ore are characterized by reaction edge structures, radial structures, and colloidal structures. The main structures of the gangue minerals are unequal granular-plate-columnar crystal structures, microscopic scale-granular crystal structures, fiber columnargranular crystal structures, and residual structures.

3.3. Mineral Compositions and Embedded Characteristics of the Ore. Through microscopic observation, XRD, electron microprobe analysis, and MLA analysis, 34 different minerals were identified in the ore, belonging to eight 

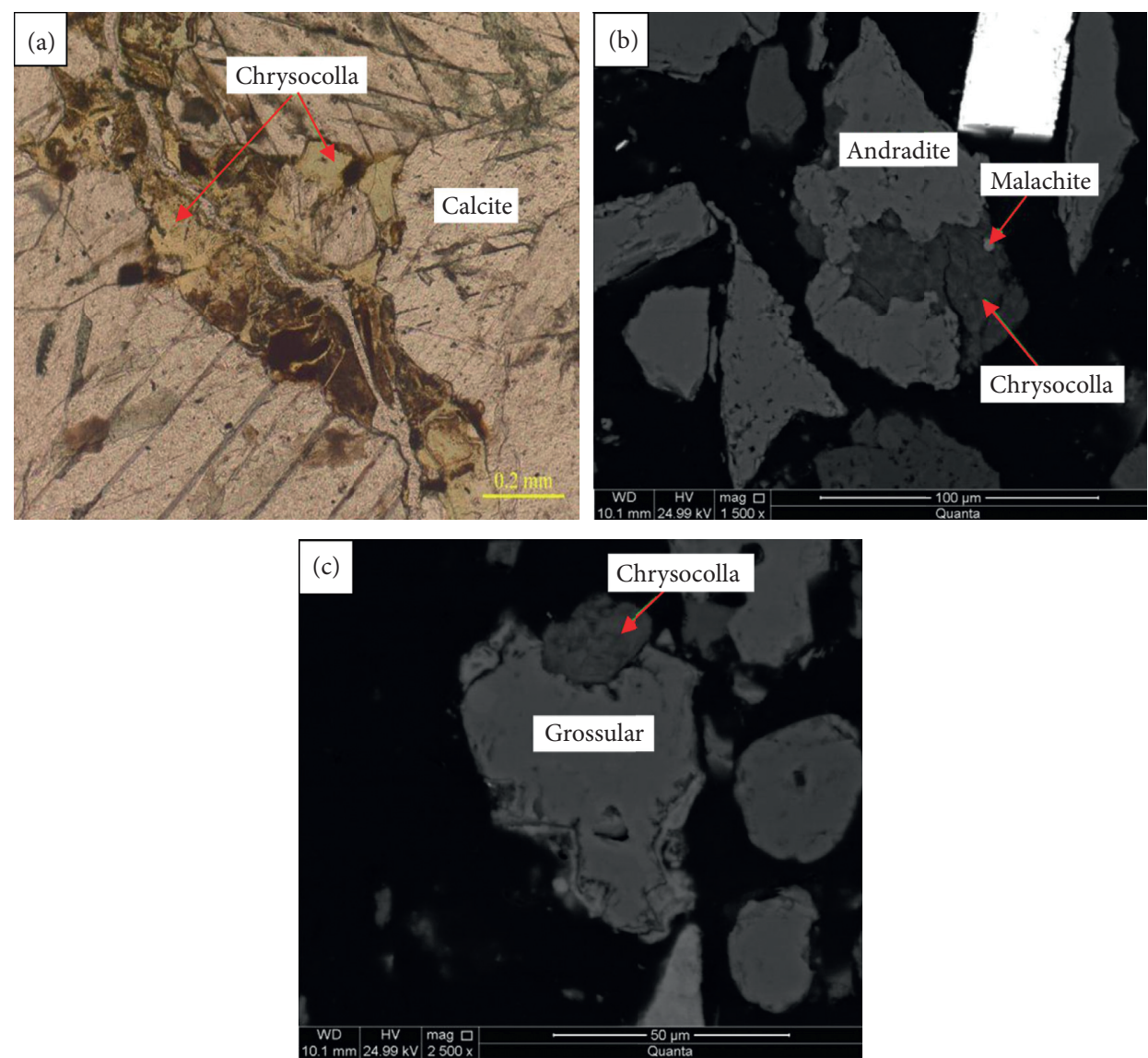

FIGURE 7: Embedded characteristics of chrysocolla.

different types of minerals: sulfides, oxides, silicates, phosphates, arsenates, sulfates, carbonates, and fluorides. Among these, silicates accounted for $72.31 \%$, carbonates accounted for $16.71 \%$, oxides accounted for $7.40 \%$, sulfides accounted for $1.23 \%$, fluorides accounted for $0.95 \%$, arsenates accounted for $0.81 \%$, phosphates accounted for $0.34 \%$, and sulfuric acid salts accounted for $0.21 \%$. The XRD analysis results for the ore are shown in Figure 1 and the mineral composition and dissemination particle size are shown in Table 5 .

Figure 1 indicates large proportions of calcite, quartz, wollastonite, and andradite in the ore and that they are gangue minerals. The useful mineral content was low; they could not be detected using this method because it was limited by the detection accuracy of XRD equipment. Therefore, the useful minerals needed to be further investigated by other detection means.

Table 5 shows that the useful minerals and gangue minerals in the ore were finer in size and that the copper minerals show more complex dissemination conditions with more kinds of minerals but lower contents. Many gangue minerals such as quartz, calcite, andradite, and essonite have high contents in the ore. The useful minerals and gangue minerals are similar in particle size, which makes flotation of useful minerals difficult.

\subsection{Embedded Characteristics of Valuable Minerals}

3.4.1. Embedded Characteristics of Copper Minerals. Chalcopyrite $\left(\mathrm{CuFeS}_{2}\right)$ : brass yellow, metallic luster, opaque, hardness 3-4, specific gravity 4.1-4.3. Under the microscope, the chalcopyrite in the ore is mostly granular and irregularly adjoining; some are in the shape of puzzle pieces and the rules are adjacent to each other (Figure $2(\mathrm{~d})$ ). Chalcopyrite is most often associated with sphalerite (Figure 2(a)), and some is associated with galena or wrapped in sphalerite or limonite (Figures 2(b) and 2(c)). Chalcopyrite occasionally occurs with enargite, bornite, chalcocite, or covellite along the edge of the chalcopyrite. The main elemental contents in chalcopyrite were $\mathrm{Cu} 34.609 \%$, Fe 30.265\%, and S 34.646\%, based on electron microprobe analysis. Chalcopyrite is a typical sulfide mineral, and the simple structure of chalcopyrite can be recovered by flotation. However, it is difficult to recover chalcopyrite associated with other minerals, such as chalcopyrite wrapped with other minerals. Therefore, it is necessary to strictly control the fineness of grinding to reduce the overgrinding of single chalcopyrite grains while simultaneously ensuring monomer dissociation of chalcopyrite associated and wrapped with other minerals.

The MLA analysis results indicate that the chalcocite in the ore is granular, mostly associated with chalcopyrite, ellestadite, diopside, and calcite, with a smaller amount 

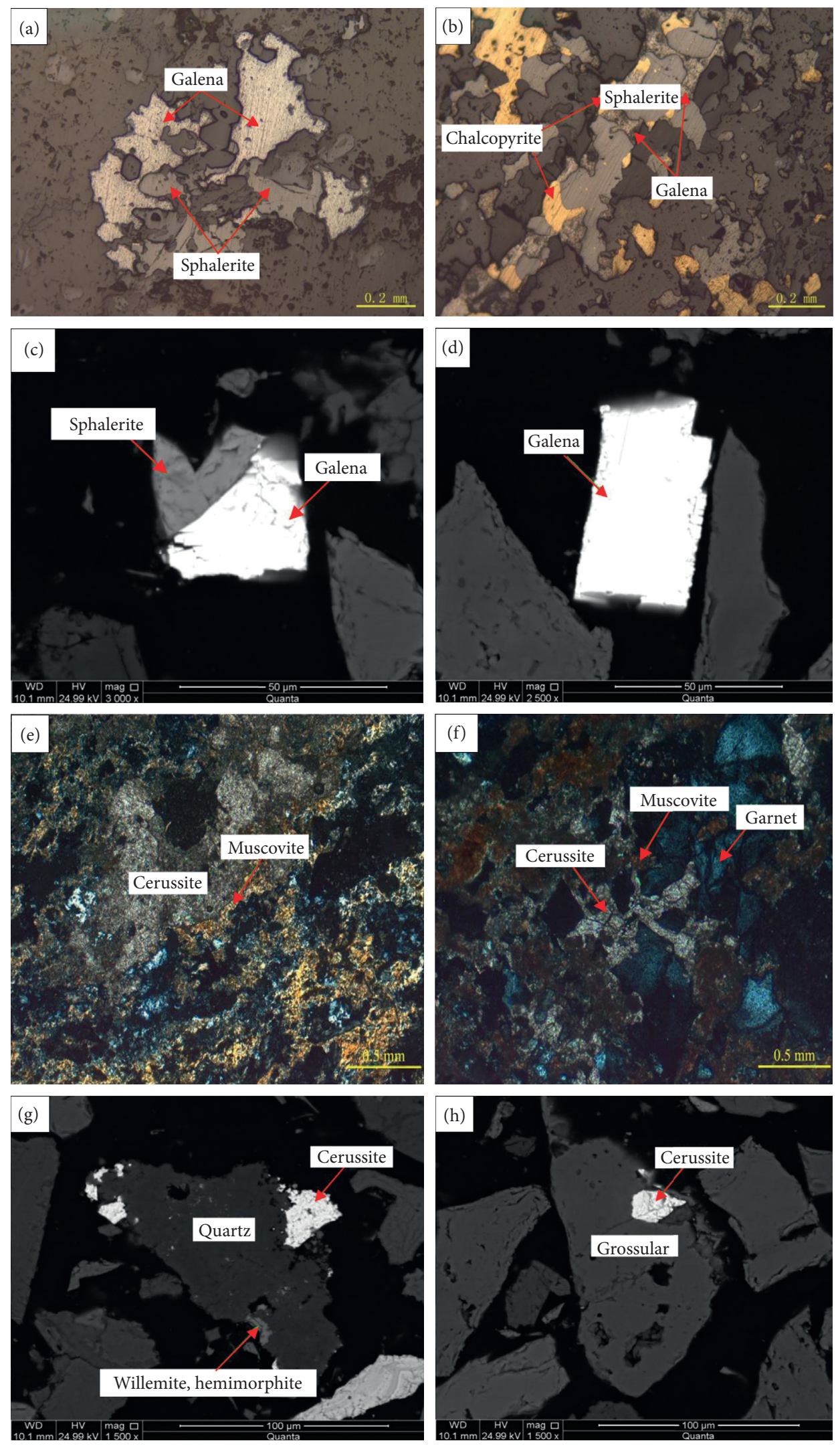

Figure 8: Embedded characteristics of galena and cerussite. 

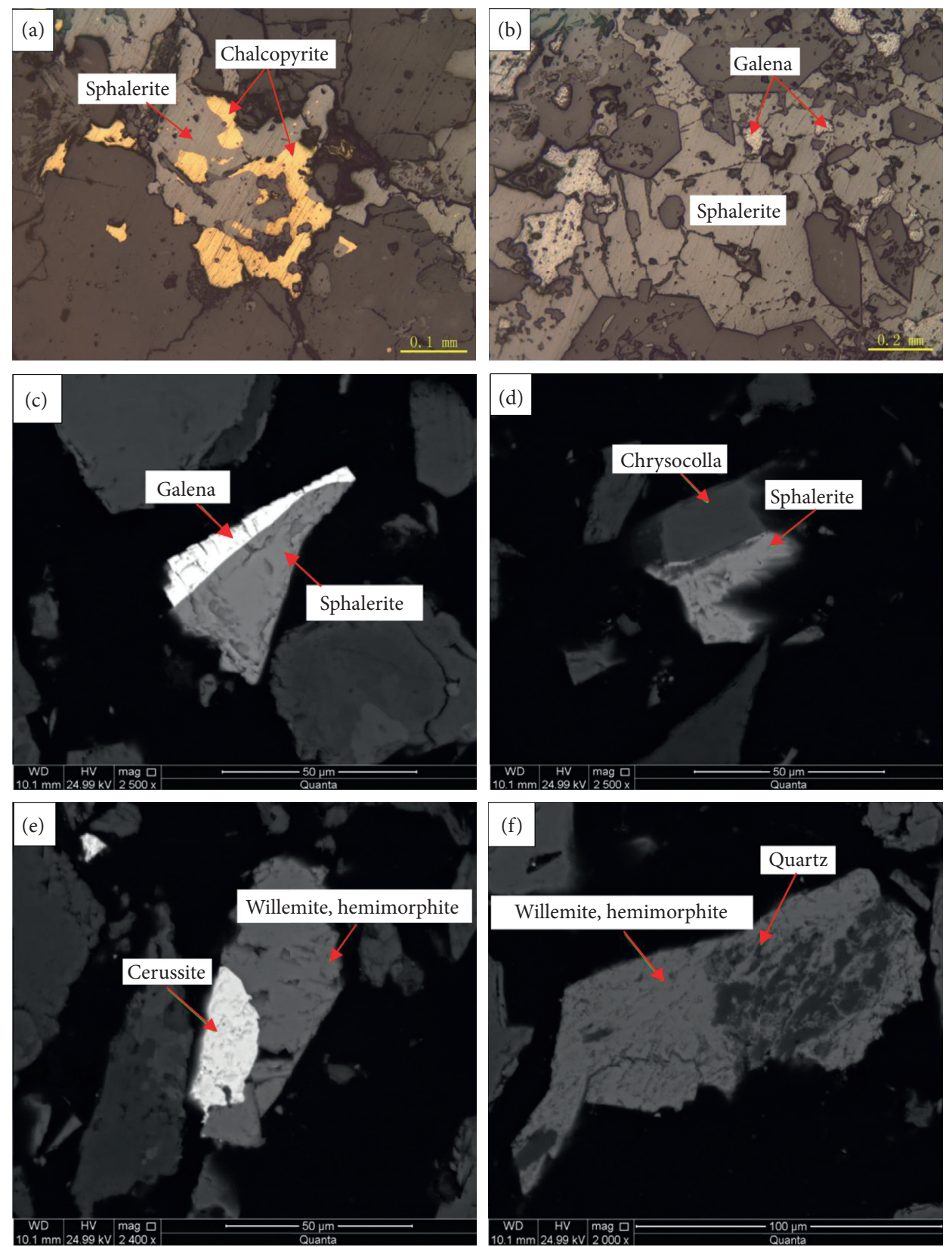

FIGURE 9: Embedded characteristics of sphalerite, willemite, and hemimorphite.

associated with wollastonite and andradite (Figures 3(a) and 3(b)). Chalcocite was associated with useful lead minerals and gangue minerals, without wrapped conditions, and the dissociation was relatively easy. However, the gangue minerals were finer in size, which can cause the pulp to contain a large amount of mud during the flotation process and interfere with the flotation results.

Covellite (CuS): indigo, dim to metallic luster, opaque, hardness $1.5-2$, specific gravity 4.59-4.67. Under the microscope, the covellite in the ore is distributed mostly along the edges of chalcopyrite or galena (Figures 3(c)-3(f)).

Bornite $\left(\mathrm{Cu}_{5} \mathrm{FeS}_{4}\right)$ : the fresh surface is dark copper red, and the weathered surface is often dark purple; metallic luster, opaque, hardness 3, specific gravity 4.9-5.3. Under the microscope, the bornite in the ore exists in granules, which are mostly associated with chalcopyrite and tetrahedrite or distributed between chalcocite particles. Occasionally, bornite is associated with beaverite and covellite (Figures 4(a)-4(d)). The main elemental contents in the bornite are $\mathrm{Cu} 62.143 \%$, Fe $11.694 \%$, and S 25.369\%, based on electron microprobe analysis. Bornite is the main mineral of copper. It is associated and cross-distributed with useful minerals, which makes monomer dissociation difficult.

Enargite $\left(\mathrm{Cu}_{3} \mathrm{AsS}_{4}\right)$ : steel gray, black with gray or yellow, metallic luster to dull luster, opaque, hardness 3.5, specific gravity 4.3-4.5. The MLA analysis results showed that enargite in the ore is granular, mostly associated with chalcopyrite, cerussite, and sphalerite, with a smaller 

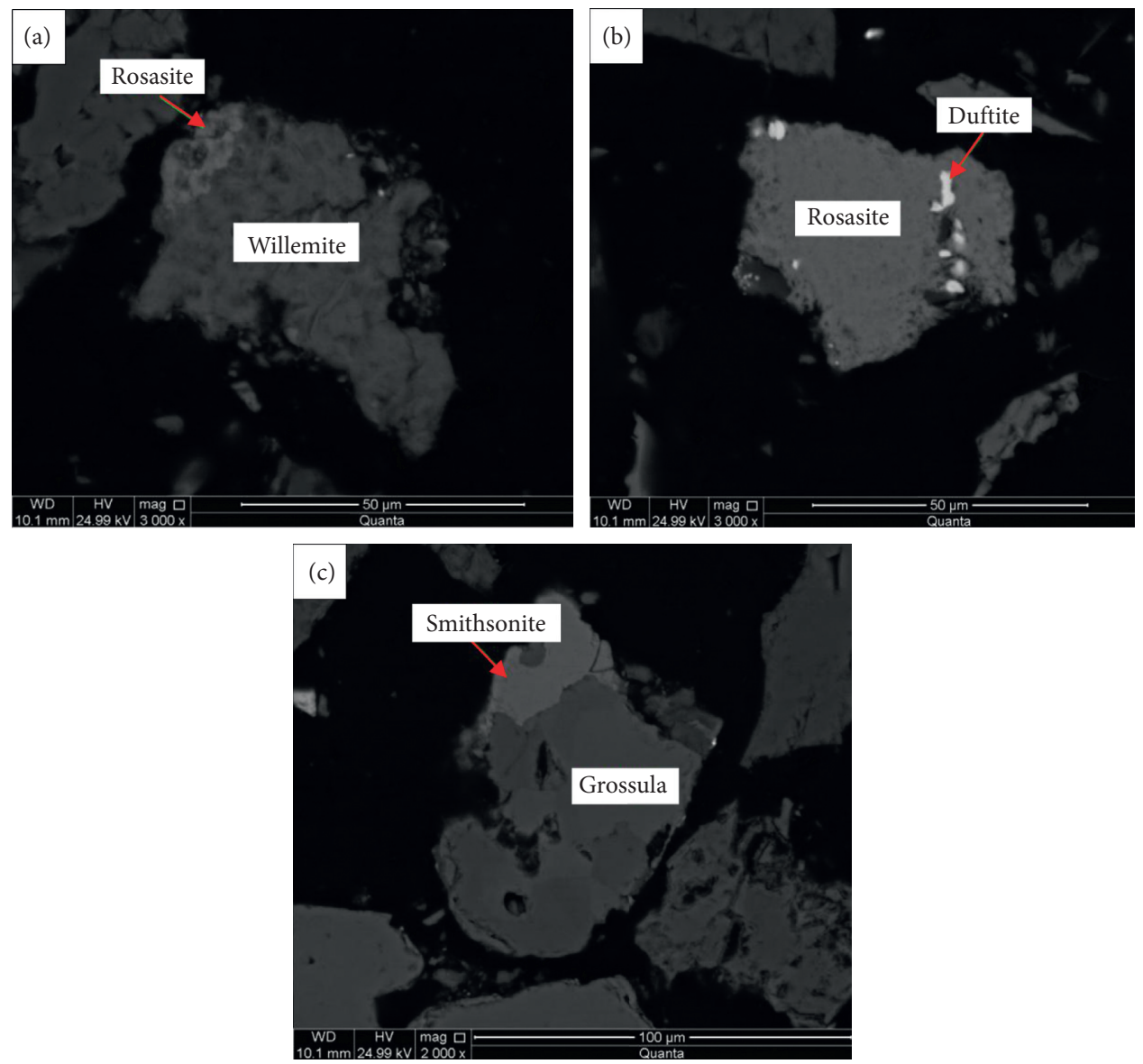

Figure 10: Embedded characteristics of rosasite and smithsonite.

amount associated with duftite, limonite, and grossular; occasionally, it is associated with enargite (Figures 4(e)$4(\mathrm{f}))$. According to electron probe analysis, the main elements in the sulfur-arsenic copper ore were $\mathrm{Cu} 45.516 \%$, As $14.706 \%$, and S $26.433 \%$.

Tetrahedrite $\left(\mathrm{Cu}_{12}(\mathrm{SbAs})_{4} \mathrm{~S}_{13}\right)$ : steel gray to iron black, metal to semi-metallic luster, opaque, hardness 3-4.5, specific gravity 4.6-5.1. Under the microscope, tetrahedrite in the ore is granular, mostly associated with galena and sphalerite, with a smaller amount associated with chalcopyrite, as shown in Figure 5.

Malachite $\left(\mathrm{Cu}_{2}\left(\mathrm{CO}_{3}\right)_{2}(\mathrm{OH})_{2}\right)$ : green and dark green, vitreous to adamantine luster, fibrous luster, or silky luster, hardness 3.5-4, specific gravity 4.0-4.5. Under microscope observation and MLA analysis, the malachite in the ore is mostly fibrous, and multiple malachite crystals together show radiating, globular structures. Malachite is mostly associated with chrysocolla, garnet, and chlorite, and a small amount distributed mixed with muscovite, as shown in Figure 6. Malachite is a typical free copper oxide mineral. In conditions of complete monomer dissociation, approximately $80 \%$ of malachite can be recovered by sulfidizing flotation. Therefore, the amount of sodium sulfide should be controlled in the subsequent flotation process to ensure full sulfidization without producing a depress effect.
Chrysocolla $\left(\mathrm{Cu}_{2}\left[\mathrm{SiO}_{4}\right]\right)$ : under the microscope, chrysocolla is mostly distributed between calcite particles. The MLA analysis results showed that chrysocolla was mostly associated with malachite, as shown in Figure 7. Chrysocolla is a typical refractory combination of copper oxide minerals, which was almost impossible to recover during the flotation process. Therefore, it must be recovered by hydrometallurgy.

3.4.2. Embedded Characteristics of Lead Minerals. Galena $(\mathrm{PbS})$ : lead gray, metallic luster, opaque, hardness 2-3, specific gravity 7.4-7.6. Under the microscope, the galena in the ore is in granules, which are mostly associated with chalcopyrite and sphalerite or wrapped in sphalerite. Occasionally, it is associated with tetrahedrite, covellite, and beaverite (Figures $8(\mathrm{a})-8(\mathrm{~d})$ ). Electron microprobe analysis results indicated that the main elements in the galena were $\mathrm{Pb} 85.612 \%$ and S $13.200 \%$. Galena is one of the sulfide minerals used for lead extraction. Single galenas can be recovered by flotation after monomer dissociation.

Under the microscope, cerussite $\left(\mathrm{PbCO}_{3}\right)$ in the ore is mostly associated with muscovite and garnet and occasionally associated with chlorite (Figures 8(e)-8(h)). According to the electron microprobe analysis results, some cerussite in the ore contains higher arsenic content, and the main elements are $\mathrm{As}_{2} \mathrm{O}_{5}$ 20.975\%, $\mathrm{PbO} 69.165 \%$, and $\mathrm{CO}_{2}$ 


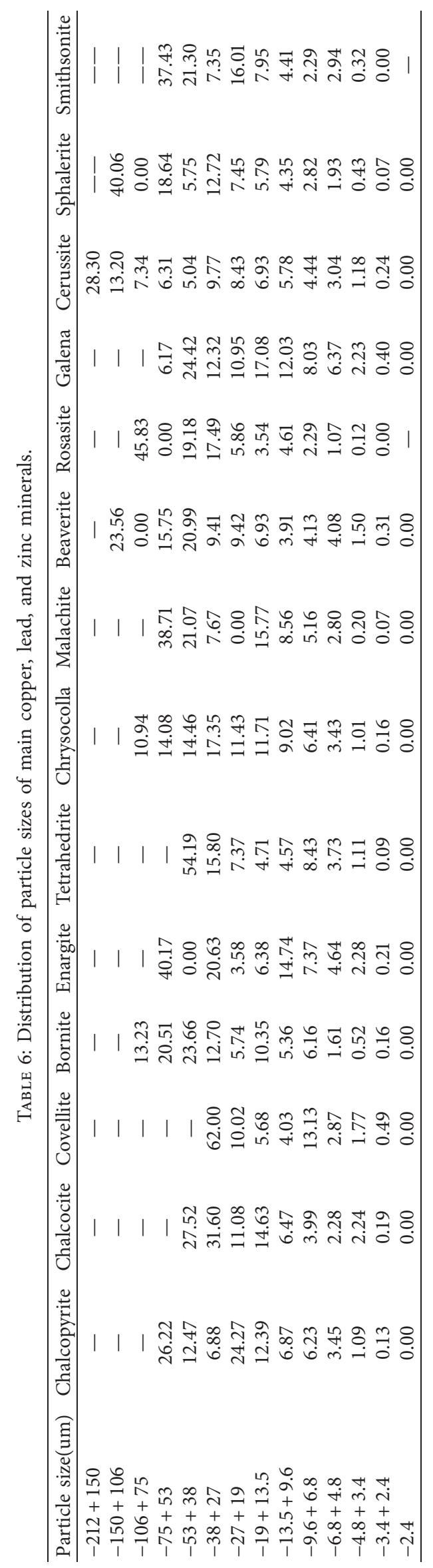


TABLe 7: Distribution of main minerals of copper, lead, and zinc (\%).

\begin{tabular}{|c|c|c|c|c|c|c|}
\hline Liberation level & 100 & $75<x<100$ & $50<x \leq 75$ & $25<x \leq 50$ & $0<x \leq 25$ & Total \\
\hline Chalcopyrite & 63.30 & 9.75 & 16.47 & 2.38 & 8.10 & 100.00 \\
\hline Chalcocite & 64.51 & 0.00 & 0.88 & 29.85 & 4.76 & 100.00 \\
\hline Covellite & 59.62 & 0.00 & 0.00 & 23.46 & 16.92 & 100.00 \\
\hline Bornite & 89.33 & 3.01 & 0.57 & 0.41 & 6.69 & 100.00 \\
\hline Enargite & 39.88 & 51.66 & 1.97 & 2.70 & 3.79 & 100.00 \\
\hline Tetrahedrite & 34.92 & 0.00 & 16.80 & 43.87 & 4.41 & 100.00 \\
\hline Chrysocolla & 49.66 & 18.21 & 3.93 & 11.02 & 17.17 & 100.00 \\
\hline Malachite & 40.28 & 32.90 & 19.83 & 2.14 & 4.85 & 100.00 \\
\hline Beaverite & 36.74 & 6.96 & 29.14 & 18.74 & 8.42 & 100.00 \\
\hline Duftite & 53.83 & 40.57 & 1.59 & 1.85 & 2.16 & 100.00 \\
\hline Rosasite & 27.05 & 69.92 & 2.17 & 0.00 & 0.85 & 100.00 \\
\hline Galena & 84.12 & 1.41 & 3.14 & 1.23 & 10.09 & 100.00 \\
\hline Cerussite & 67.90 & 8.83 & 18.12 & 1.52 & 3.63 & 100.00 \\
\hline Sphalerite & 70.81 & 4.55 & 2.21 & 1.10 & 21.34 & 100.00 \\
\hline Smithsonite & 86.28 & 0.00 & 0.00 & 0.00 & 13.72 & 100.00 \\
\hline
\end{tabular}

TABle 8: Distribution of copper in main Cu-bearing minerals.

\begin{tabular}{lcccc}
\hline Minerals & $\begin{array}{c}\text { Mineral } \\
\text { content }\end{array}$ & $\begin{array}{c}\text { Content of copper in } \\
\text { minerals }\end{array}$ & $\begin{array}{c}\text { Distribution of copper in } \\
\text { minerals }\end{array}$ & $\begin{array}{c}\text { The distribution rate of copper in main } \\
\text { Cu-bearing minerals }\end{array}$ \\
\hline Chalcopyrite & 0.27 & 34.61 & 0.0934 & 17.54 \\
Chalcocite & 0.03 & 79.86 & 0.0240 & 4.50 \\
Covellite & 0.02 & 66.48 & 0.0133 & 2.50 \\
Bornite & 0.18 & 62.14 & 0.1119 & 20.99 \\
Enargite & 0.04 & 45.52 & 0.0182 & 3.42 \\
Tetrahedrite & 0.03 & 45.77 & 0.0137 & 2.58 \\
Chrysocolla & 0.30 & 24.17 & 0.0725 & 13.61 \\
Malachite & 0.06 & 57.48 & 0.0345 & 6.47 \\
Beaverite & 0.20 & 9.60 & 0.0192 & 3.60 \\
Sphalerite & 0.25 & 0.27 & 0.0007 & 0.13 \\
Duftite & 0.80 & 13.53 & 0.1082 & 20.31 \\
Rosasite & 0.07 & 33.29 & 0.0233 & - \\
Others & 97.75 & - & 0.5329 & - \\
Totals & 100.00 & - & & 100.00 \\
\hline
\end{tabular}

Table 9: Distribution of lead in main Pb-bearing minerals (\%).

\begin{tabular}{|c|c|c|c|c|}
\hline Minerals & $\begin{array}{l}\text { Mineral } \\
\text { content }\end{array}$ & $\begin{array}{l}\text { Content of lead in } \\
\text { minerals }\end{array}$ & $\begin{array}{l}\text { Distribution of lead in } \\
\text { minerals }\end{array}$ & $\begin{array}{l}\text { The distribution rate of lead in main } \mathrm{Pb} \text {-bearing } \\
\text { minerals }\end{array}$ \\
\hline Galena & 0.21 & 85.61 & 0.1798 & 13.87 \\
\hline Cerussite & 0.98 & 76.88 & 0.7534 & 58.14 \\
\hline Beaverite & 0.20 & 31.29 & 0.0626 & 4.83 \\
\hline Duftite & 0.80 & 37.50 & 0.3000 & 23.15 \\
\hline Others & 97.81 & - & - & - \\
\hline Totals & 100.00 & - & 1.2958 & 100.00 \\
\hline
\end{tabular}

9.336\%. Some cerussite does not contain arsenic, and the main elemental contents are $\mathrm{PbO} 82.823 \%$ and $\mathrm{CO}_{2} 16.471 \%$. Cerussite is a lead oxide mineral that can be recovered by flotation of sulfide-xanthate.

3.4.3. Embedded Characteristics of Zinc Minerals. Sphalerite (ZnS): greasy to semi-metallic luster, transparent to translucent, hardness 3.5-4, specific gravity 3.9-4.2. Under the microscope, the sphalerite in the ore is in granules, mostly associated with chalcopyrite. A small number of sphalerites and chalcopyrites are intertwined with each other or associated with galena, and occasionally associated with tetrahedrite, enargite, and beaverite (Figures 9(a)-9(d)). The contents of the main elements in sphalerite were $\mathrm{Zn} 66.229 \%$ and S 32.444\%, based on electron microprobe analysis. Sphalerite is the main zinc-containing sulfide and can be recycled by flotation after liberation.

Wollastonite $\left(\mathrm{Zn}_{2}\left(\mathrm{SiO}_{4}\right)\right)$ and hemimorphite $\left(\mathrm{Zn}_{4}\left(\mathrm{H}_{2} \mathrm{O}\right)\right.$ $\left.\left[\mathrm{Si}_{2} \mathrm{O}_{7}\right](\mathrm{OH})_{2}\right)$ : the MLA analysis results showed that wollastonite was mostly associated with quartz and diopside and occasionally associated with malachite and cerussite (Figures 9(e)-9(f)). 
Table 10: Distribution of zinc in main Zn-bearing minerals (\%).

\begin{tabular}{|c|c|c|c|c|}
\hline Minerals & $\begin{array}{l}\text { Mineral } \\
\text { content }\end{array}$ & $\begin{array}{l}\text { Content of zinc in } \\
\text { minerals }\end{array}$ & $\begin{array}{l}\text { Distribution of zinc in } \\
\text { minerals }\end{array}$ & $\begin{array}{l}\text { The distribution rate of zinc in main } \mathrm{Zn} \text {-bearing } \\
\text { minerals }\end{array}$ \\
\hline Sphalerite & 0.25 & 66.23 & 0.1656 & 30.50 \\
\hline Willemite & 0.52 & 58.55 & 0.3045 & 56.09 \\
\hline Smithsonite & 0.08 & 51.28 & 0.0410 & 7.56 \\
\hline Duftite & 0.80 & 1.39 & 0.0111 & 2.05 \\
\hline Chrysocolla & 0.07 & 23.79 & 0.0167 & 3.07 \\
\hline Austinite & 0.01 & 25.01 & 0.0025 & 0.46 \\
\hline Enargite & 0.04 & 3.64 & 0.0015 & 0.27 \\
\hline Others & 98.23 & - & - & - \\
\hline Total & 100.00 & - & 0.5428 & 100.00 \\
\hline
\end{tabular}

Rosasite $\left(\mathrm{ZnCu}\left[\mathrm{CO}_{3}\right](\mathrm{OH})_{2}\right)$ : the MLA analysis results indicated that rosasite in the ore was mostly associated with cerussite, wollastonite, hemimorphite, and quartz, with a smaller amount associated with duftite (Figures 10(a) and 10(b)).

Smithsonite $\left(\mathrm{ZnCO}_{3}\right)$ : the MLA analysis results indicated that smithsonite in the ore was mostly associated with grossular and occasionally associated with diopside and albite (Figure 10(c)). Wollastonite, hemimorphite, rosasite, and smithsonite are zinc oxide minerals, which can be recovered by sulfide-xanthate or sulfide-ammonium flotation. Generally, the effect of sulfide-ammonium flotation is better than that of sulfide-xanthate flotation. However, because of the low zinc content of the ore, the use of sulfide-ammonium flotation alone in the recovery of zinc oxide minerals may greatly affect the recovery of copper and lead minerals in the ore and lead to loss of valuable copper and lead resources without economic value. Therefore, sulfide-ammonium flotation was used to comprehensively recover the copper, lead, and zinc resources.

\subsection{Embedded Granularity Characteristics of Main Minerals}

3.5.1. Granularity Characteristics of Main Minerals. The sample was crushed to $0.3 \mathrm{~mm}$ grain size, and the particle size distribution characteristics of the useful minerals were analyzed by MLA; the results are shown in Table 6. The particle sizes of chalcopyrite, chalcocite, covellite, bornite, enargite, tetrahedrite, chrysocolla, malachite, rosasite, galena, willemite, and hemimorphite overall are very fine.

3.5.2. Liberation Characteristics of Main Minerals. The liberation degree of the copper-lead-zinc carrier minerals is an important factor affecting the beneficiation index and is an important basis for projecting mineral processing products. Mineral liberation degree analysis was performed on $0.3 \mathrm{~mm}$ samples using MLA; the results are shown in Table 7 . Table 7 shows that the liberation degree distribution of useful minerals varies greatly, with degrees of liberation between $27 \%$ and $89 \%$, which makes it difficult to determine the fineness of ore grinding. Therefore, the fineness of grinding could be determined by the fineness of grinding in the later test and the relationship flotation index.

\subsection{Copper, Lead, and Zinc Occurrence State}

3.6.1. Copper Occurrence State. Chemical analysis showed that the content of copper in the ore was $0.53 \%$. The detection and analysis results showed that copper was found mainly in bornite, duftite, chalcopyrite, and chrysocolla, with some also in malachite, chalcocite, rosasite, beaverite, enargite, tetrahedrite, covellite, and sphalerite. The distribution rate of copper in the main copper-bearing minerals is shown in Table 8 . The results show that the occurrence state of copper is complex, there are many different minerals, and it is difficult to separate chrysocolla. To improve the grade and recovery rate of copper, copper sulfide minerals in ores need to be completely floated, and copper oxide minerals that float easily should be effectively recovered during flotation.

3.6.2. Lead Occurrence State. Chemical analysis showed that the $\mathrm{Pb}$ content in the ore was $1.29 \%$. Analysis of the microscopic, XRD, MLA, and electron microprobe results showed that lead was found mainly in cerussite, duftite, and galena, with some also in beaverite. Table 9 shows the distribution ratios among the main lead-containing minerals. Lead oxide minerals accounted for more than $70 \%$ of the total lead and are recovered by the sulfurized-xanthate method; thus, most oxidized minerals are selected, thereby increasing the lead recovery rate.

3.6.3. Zinc Occurrence State. Chemical analysis showed that the content of $\mathrm{Zn}$ in the ore was $0.54 \%$. The microscopic, XRD, MLA, and electron microprobe results showed that zinc was found mainly in willemite, hemimorphite, and sphalerite, with some also in smithsonite, rosasite, duftite, and enargite. Table 10 shows the calculation of the distribution ratio of zinc in each of the main zinc-containing minerals.

\section{Conclusions}

The mineral composition of the raw ore is very complex, and the main valuable elements are $\mathrm{Cu}, \mathrm{Pb}$, and $\mathrm{Zn}$, and copper minerals mainly existing in the forms of copper sulfide and copper oxide. Among them, copper sulfide and free copper oxide are the main objects to be recovered. Lead minerals mainly exist in the forms of carbonates, sulfates, and sulfides, 
and lead carbonate and lead sulfide are the main objects to be recovered. Zinc minerals mainly exist in the form of zinc oxide, followed by zinc sulfide, among which smithsonite and sphalerite should mainly be recovered. The high oxidation rates of copper, lead, and zinc may be attributed to an important reason for the low recovery of targeted minerals. The main structures of the metal minerals are inclusion structures, reaction edge structures, radial structures, and colloidal structures. The distribution of valuable elements is relatively scattered, and different minerals exist in the form of fine-grained dissemination, from which mineral liberation is difficult to achieve. Therefore, the grinding fineness should be strictly determined to guarantee the degree of mineral liberation and facilitate the efficient recovery of valuable minerals. These results indicate that valuable minerals in ore can be first enriched by bulk flotation, and copper, lead, and zinc obtained in flotation concentrate can be further separated by oxidation roasting and hydrometallurgy.

\section{Data Availability}

The data used to support the findings of this study are included within the article.

\section{Conflicts of Interest}

The authors declare no conflicts of interest.

\section{Acknowledgments}

The authors would like to acknowledge the project funding from National Natural Science Foundation of China (No. 51804144) and Applied Basic Research Foundation of Yunnan Province (No. 2018FD035).

\section{References}

[1] Y. J. Wang, Y. Z. Xu, M. Pan, and W. Shuming, "Mineralogical characteristics of direct reduction titanium slag at Panzhihua," Journal of Central South University, vol. 50, pp. 497-505, 2019.

[2] G. Barbery, "Complex sulphide ores: processing options," Mineral Processing at a Crossroads, Springer, Dordrecht, Netherlands, 1986.

[3] G. H. Ai, Z. F. Xie, and H. S. Yan, "Research on technological mineralogy of a copper-lead-zinc ore," Mining \& Processing Equipment, vol. 42, pp. 109-112, 2014.

[4] T. S. Qiu, Z. F. Xie, and X. Huang, "Process mineralogy and beneficiation test of a copper lead-zinc ore," Mining and Metallurgy, vol. 24, pp. 89-93, 2015.

[5] L. Wang, K. H. Luo, and Z. Y. Li, "Process mineralogy of a gold multi-metal ore in Beiya, Yunna," Procedia Environmental Science, vol. 12, no. Part B, pp. 949-956, 2012.

[6] J. W. Yu, P. Gao, and Y. X. Han, "Mineralogical characteristics and comprehensive utilization of boron containing concentrate," Journal of Central South University (Science and Technology), vol. 46, no. 8, pp. 2785-2790, 2015.

[7] S. Nthapo, S. Zandile, B. Mike, and L. Lindvelt, "Flowsheet development for selective $\mathrm{Cu}-\mathrm{Pb}-\mathrm{Zn}$ recovery at Rosh Pinah concentrator," Minerals Engineering, vol. 122, pp. 10-16, 2018.
[8] J. Nouairi, W. Hajjaji, C. S. Costa et al., "Study of Zn-Pb ore tailings and their potential in cement technology," Journal of African Earth Sciences, vol. 139, pp. 165-172, 2018.

[9] Y.-m. Chen, X. Xie, X. Tong, and H.-z. Lv, "Mineralogical characterisation of an Ag-In-Bearing polymetallic ore with regard to its mineral separation behaviour," Russian Journal of Non-ferrous Metals, vol. 59, no. 1, pp. 16-22, 2018.

[10] G. Q. Li, "Research on recovery of sulfide ore from complex copper-lead-zinc ore by new mixed flotation process," Hunan Non-Ferrous Metals, vol. 25, pp. 8-12, 2009.

[11] H. J. Yan, Y. Xiang, and Y. S. Song, "Floatation of fine disseminated $\mathrm{Cu}-\mathrm{Pb}-\mathrm{Zn}$ polymetallic ore," Chinese Journal of Rare Metals, vol. 34, pp. 731-736, 2010.

[12] S. Moradi and A. J. Monhemius, "Mixed sulphide-oxide lead and zinc ores: problems and solutions," Minerals Engineering, vol. 24, no. 10, pp. 1062-1076, 2011.

[13] S. M. Bulatovic, "Flotation of mixed lead zinc sulphide oxide and oxide lead and zinc ores," Handbook of Flotation Reagents: Chemistry, Theory and Practice, Elsevier, Amsterdam, Netherlands, pp. 67-86, 2010.

[14] Y. Zhang, B. Jin, Y. Huang, Q. Song, and C. Wang, "Two-stage leaching of zinc and copper from arsenic-rich copper smelting hazardous dusts after alkali leaching of arsenic," Separation and Purification Technology, vol. 220, pp. 250-258, 2019.

[15] M. Ye, G. Li, P. Yan et al., "Removal of metals from lead-zinc mine tailings using bioleaching and followed by sulfide precipitation," Chemosphere, vol. 185, pp. 1189-1196, 2017.

[16] B. K. Przemyslaw, B. Snook, A. K. Rolf, and A. Kurt, "Efficient extraction of copper and zinc from seafloor massive sulphide rock samples from the Loki's Castle area at the Arctic MidOcean Ridge," Minerals Engineering, vol. 115, pp. 106-116, 2018.

[17] J. Esmaeil and G. Ahmad, "Challenges with elemental sulfur removal during the leaching of copper and zinc sulfides, and from the residues; a review," Hydrometallurgy, vol. 171, pp. 333-343, 2017.

[18] L. H. Sarah, E. T. Joan, F. Daniel, and R. G. Andrea, "The evolution of surface layers formed during chalcopyrite leaching," Geochimica et Cosmochimica Acta, vol. 70, pp. 4392-4402, 2006.

[19] B. A. Wills, Wills' Mineral Processing Technology: An Introduction to the Practical Aspects of Ore Treatment and Mineral recovery, Pergamon Press, Oxford, UK, 1988.

[20] M. M. Antonijevic and G. D. Bogdanovic, "Investigation of the leaching of chalcopyritic ore in acidic solutions," $\mathrm{Hy}$ drometallurgy, vol. 73, no. 3-4, pp. 245-256, 2004.

[21] E. M. Córdoba, J. A. Muñoz, M. L. Blázquez, F. González, and A. Ballester, "Leaching of chalcopyrite with ferric ion. Part I: general aspects," Hydrometallurgy, vol. 93, no. 3-4, pp. 81-87, 2008.

[22] F. Natalya, U. Taisiia, and M. Maxim, "Effect of mineral composition of sulfidic polymetallic concentrates on nonferrous metals bioleaching," Minerals Engineering, vol. 138, pp. 1-6, 2019.

[23] X. Huang, K. Huang, Y. Jia, S. Wang, Z. Cao, and H. Zhong, "Investigating the selectivity of a xanthate derivative for the flotation separation of chalcopyrite from pyrite," Chemical Engineering Science, vol. 205, pp. 220-229, 2019.

[24] G. Han, S. Wen, H. Wang, and Q. Feng, "Selective adsorption mechanism of salicylic acid on pyrite surfaces and its application in flotation separation of chalcopyrite from pyrite," Separation and Purification Technology, vol. 240, p. 116650, 2020. 
[25] X. Wang, W. Qin, F. Jiao, R. Liu, and D. Wang, "Inhibition of galena flotation by humic acid: identification of the adsorption site for humic acid on moderately oxidized galena surface," Minerals Engineering, vol. 137, pp. 102-107, 2019.

[26] L. Zha, H. Li, and N. Wang, "Preparation of high purity compact galena bulk by hot pressed sintering," Materials Letters, vol. 234, pp. 233-236, 2019.

[27] B. Vasanthakumar, H. Ravishankar, and S. Subramanian, "Selective bio-flotation of sphalerite from galena using mineral-adapted strains of Bacillus subtilis," Minerals Engineering, vol. 110, pp. 179-184, 2017.

[28] M. Ejtemaei and A. V. Nguyen, "Characterisation of sphalerite and pyrite surfaces activated by copper sulphate," Minerals Engineering, vol. 100, pp. 223-232, 2017.

[29] X. R. Zhang, Y. G. Zhu, G. B. Zheng et al., "An investigation into the selective separation and adsorption mechanism of a macromolecular depressant in the galena-chalcopyrite system," Minerals Engineering, vol. 134, pp. 291-299, 2019.

[30] S. Özün and G. Ergen, "Determination of optimum parameters for flotation of galena: effect of chain length and chain structure of xanthates on flotation recovery," ACS Omega, vol. 4, no. 1, pp. 1516-1524, 2019.

[31] M. D. Seke and P. C. Pistorius, "Effect of cuprous cyanide, dry and wet milling on the selective flotation of galena and sphalerite," Minerals Engineering, vol. 19, no. 1, pp. 1-11, 2006.

[32] S. Ozun, H. B. Vaziri, and J. D. Miller, "Collectorless flotation of oxidized pyrite," Colloids and Surfaces A: Physicochemical and Engineering Aspects, vol. 561, pp. 349-356, 2018.

[33] W. J. Trahar and L. J. Warren, "The flotability of very fine particles-a review," International Journal of Mineral Processing, vol. 3, no. 2, pp. 103-131, 1976.

[34] M. R. Jakhu, "Beneficiation of complex sulphide ores at hindustan zinc limited, India," Mineral Processing and Extractive Metallurgy Review, vol. 15, no. 1-4, p. 47, 1995.

[35] D. Z. Chen, "Design and production practice in Jiama polymetallic copper concentrator in Tibet," Non-Ferreous Metals, vol. 2, pp. 30-34, 2011.

[36] J. H. Liu and S. Z. Liu, "Flotation of refractory $\mathrm{Cu}-\mathrm{Pb}-\mathrm{Zn}$ polymetallic ore in Fujian," Non-Ferreuos Metals, vol. 4, pp. 11-16, 2017.

[37] Q. Zhang, S. M. Wen, Q. C. Feng, W. L. Nie, and D. D. Wu, "Dissolution kinetics of hemimorphite in methane sulfonic acid," Physicochemical Problems of Mineral Processing, vol. 55, pp. 1-9, 2019.

[38] W. Zhao, D. Liu, and Q. Feng, "Enhancement of salicylhydroxamic acid adsorption by $\mathrm{Pb}(\mathrm{II})$ modified hemimorphite surfaces and its effect on floatability," Minerals Engineering, vol. 152, p. 106373, 2020. 